\title{
Oxidative Stress in the Male Germline: A Review of Novel Strategies to Reduce 4-Hydroxynonenal Production
}

\author{
Jessica L. H. Walters, Geoffry N. De Iuliis, Brett Nixon +(i) and Elizabeth G. Bromfield *,+([) \\ Priority Research Centre for Reproductive Science, School of Environmental and Life Sciences, Discipline of \\ Biological Sciences, University of Newcastle, Callaghan, NSW 2380, Australia; jwalters1@uon.edu.au (J.L.H.W.); \\ geoffry.deiuliis@newcastle.edu.au (G.N.D.I.); Brett.nixon@newcastle.edu.au (B.N.) \\ * Correspondence: Elizabeth.bromfield@newcastle.edu.au; Tel.: +61-2-4921-6267 \\ t These authors contributed equally to this work.
}

Received: 16 August 2018; Accepted: 26 September 2018; Published: 3 October 2018

check for updates

\begin{abstract}
Germline oxidative stress is intimately linked to several reproductive pathologies including a failure of sperm-egg recognition. The lipid aldehyde 4-hydroxynonenal (4HNE) is particularly damaging to the process of sperm-egg recognition as it compromises the function and the stability of several germline proteins. Considering mature spermatozoa do not have the capacity for de novo protein translation, $4 \mathrm{HNE}$ modification of proteins in the mature gametes has uniquely severe consequences for protein homeostasis, cell function and cell survival. In somatic cells, 4HNE overproduction has been attributed to the action of lipoxygenase enzymes that facilitate the oxygenation and degradation of $\omega-6$ polyunsaturated fatty acids (PUFAs). Accordingly, the arachidonate 15-lipoxygenase (ALOX15) enzyme has been intrinsically linked with $4 \mathrm{HNE}$ production, and resultant pathophysiology in various complex conditions such as coronary artery disease and multiple sclerosis. While ALOX15 has not been well characterized in germ cells, we postulate that ALOX15 inhibition may pose a new strategy to prevent 4HNE-induced protein modifications in the male germline. In this light, this review focuses on (i) $4 \mathrm{HNE}$-induced protein damage in the male germline and its implications for fertility; and (ii) new methods for the prevention of lipid peroxidation in germ cells.
\end{abstract}

Keywords: male fertility; oxidative stress; 4-hydroxynonenal (4HNE); arachidonate 15-lipoxygenase (ALOX15); lipid peroxidation; reactive oxygen species (ROS)

\section{Introduction: Fertility and Oxidative Stress}

A decline in fertility rates is becoming an increasingly prevalent issue worldwide, with current estimates indicating that 1 in every 6 couples experience issues with conception [1]. Furthermore, the contribution of male factor infertility accounts for up to half of these cases [2]. The leading cause of male infertility stems from a loss of sperm function, ultimately resulting in a loss of fertilization potential [3]. This loss in function is causatively linked to oxidative stress within the cell $[4,5]$ driven by the presence and/or overproduction of intracellular reactive oxygen species (ROS). Reactive oxygen species are oxygen-containing molecules that can contain unpaired electrons (radicals) or be non-radical oxidizing agents [6]. The consequences of ROS are realized through redox reactions with a great number of biological substrates, producing either further reactive products or oxidized biomolecules. Within spermatozoa, low levels of ROS are essential for promoting key stages of development. For instance, ROS actively participate in metabolic pathways during sperm activation, which leads to cholesterol efflux, cyclic adenosine monophosphate (cAMP) production and tyrosine phosphorylation, important events that contribute to fertilization competence [5,7-9]. 
However, if intracellular ROS production escalates beyond the buffering antioxidant capacity of the cell in a state of oxidative stress, the redox biochemistry leads to damaging effects such as lipid peroxidation, organelle degradation, DNA damage and eventually cell death [10,11]. Typically, antioxidants, which counteract and protect against oxidative stress, are housed within the cytoplasm and mitochondria of somatic cells $[12,13]$. However, spermiogenesis, a process that gives rise to the unique architecture of mature spermatozoa, results in significant cytoplasmic depletion [14,15], thereby diminishing antioxidant capacity in the spermatozoon [16]. Furthermore, during testicular maturation, there is an enrichment of long chain poly-unsaturated fatty acids (PUFAs) in the sperm plasma membrane, which can serve as important substrates for lipid peroxidation [10]. Indeed, PUFAs such as arachidonic acid, linoleic acid and docosahexaenoic acid are enriched within the sperm plasma membrane $[17,18]$, and can be broken down into cytotoxic lipid aldehydes that promote cellular damage and the dysregulation of cell function [19]. Common metabolites of lipid peroxidation within spermatozoa include reactive aldehyde compounds such as 4-hydroxynonenal (4HNE) and malondialdehyde (MDA) [19-21]. Herein, we review literature pertaining to the reactivity, production and prevention of these cytotoxic lipid peroxidation products in the male germline.

\section{Aldehydes in the Male Germline}

In developing male germ cells and mature spermatozoa, two of the primary aldehyde products of lipid peroxidation that have been reported to cause cellular damage are MDA and 4HNE [19,22]. Increased levels of MDA are linked to a reduction in sperm concentration, normal morphology and motility $[23,24]$. Similarly, MDA is present at higher levels within the sperm of infertile men and is thought to initiate a loss of motility, reduction in sperm concentration and atypical morphology [24]. The levels of $4 \mathrm{HNE}$ within spermatozoa are positively correlated with mitochondrial superoxide formation [10], suggesting that elevated levels of 4HNE place sperm cells under increased levels of oxidative stress. Accordingly, the presence of $4 \mathrm{HNE}$ has been linked to numerous adverse effects on sperm function including a decline in motility, morphology, the capacity to acrosome react, and to engage in interactions with the zona pellucida of oocytes $[19,25,26]$. Specifically, the exposure of biomolecules to $4 \mathrm{HNE}$ stimulates an upregulation of mitochondrial ROS, generating a cascade of oxidative stress within human spermatozoa [19], as depicted in Figure 1.

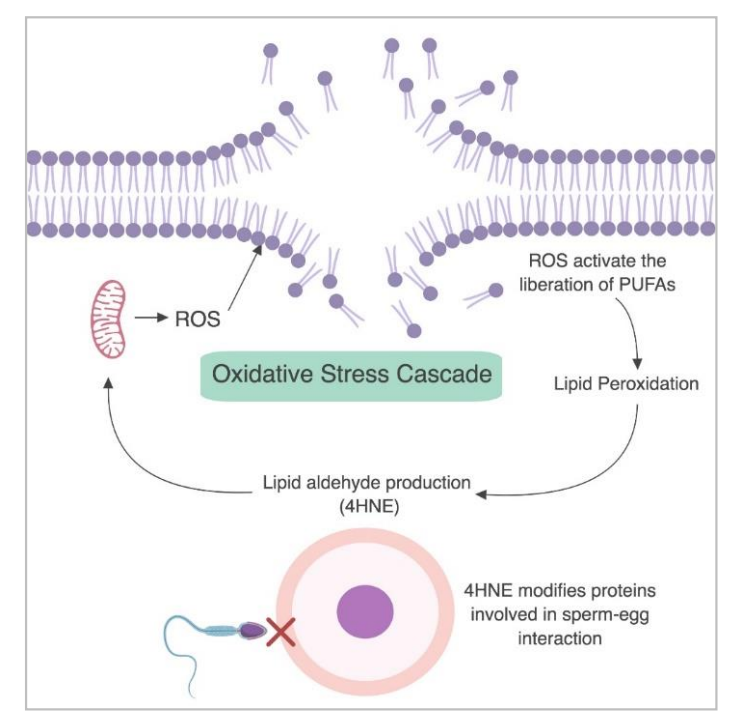

Figure 1. The cascade of oxidative stress in human spermatozoa. Mitochondrial reactive oxygen species (ROS) are produced and initiate the breakdown of the lipid plasma membrane. This promotes lipid peroxidation and the production of cytotoxic lipid aldehydes such as 4-hydroxynonenal (4HNE). In turn, 4HNE upregulates ROS production while causing an overall decline in cell function, ultimately impairing sperm-egg interaction. Figure created with BioRender. 
Overproduction of $4 \mathrm{HNE}$ within sperm cells is linked to a reduction in sperm motility [26] and sperm-zona pellucida (ZP) interaction mediated by the molecular chaperone heat shock protein A2 (HSPA2) [25], and an increase in cell death [19]. There are several non-enzymatic pathways for aldehyde production, the best characterized being Fenton reactions, whereby ferrous iron $\left(\mathrm{Fe}^{2+}\right)$ within the cell is able to interact with lipids $(\mathrm{LOOH})$ allowing the formation of lipid hydroperoxides ( $\mathrm{LO}^{\bullet}$ ) as shown in Equation (1) [27] and the production of aldehydes (as reviewed by Spiteller and Ayala et al.) [20,27].

$$
\mathrm{LOOH}+\mathrm{Fe}^{2+} \rightarrow \mathrm{LO} \bullet+\mathrm{Fe}^{3+}+\mathrm{OH} \bullet
$$

Importantly, $4 \mathrm{HNE}$ is also produced via enzymatic pathways involving lipoxygenases such as arachidonate 15-lipoxygenase (ALOX15), with several studies highlighting that key metabolites such as 13-HpODE lead to the production of 4 HNE $[20,28]$, while MDA appears to be synthesized independent of lipoxygenase activity [29]. 4-hydroxynonenal is considered to be the most toxic lipid aldehyde produced within the cell [30]. This is due, at least in part, to its reactivity and subsequent capacity to alkylate proteins, generate DNA damage and ultimately cause cell death $[19,25,26,31]$. The reactivity of $4 \mathrm{HNE}$ lies in its ability to form Schiff bases and/or participate in Michael reactions. The preferential biological targets for these reactions are proteins, specifically primary amines such as lysine, but reactions with cysteine and histidine amino acid residues are also common [32,33]. A particular target for 4HNE adduction is succinate dehydrogenase (SDH) [19], a key protein in the electron transport chain within the mitochondria. Excess 4 HNE has been shown to form adducts with $\mathrm{SDH}$, which result in a loss of function. This ultimately facilitates electron leakage to electron acceptors in an unregulated fashion, increasing the production of ROS and eventually precipitating a state of oxidative stress within the cell [19]. Another such example in human spermatozoa is the molecular chaperone HSPA2 [34], which is also targeted for adduction by 4HNE [25]. Such modifications of HSPA2 results in a loss of its chaperoning ability and thus significantly attenuates the ability of the protein to coordinate the expression of receptors on the sperm surface; a maturational event that is critical for sperm-egg recognition [25]. Ultimately, this sequence of events culminates in a severely reduced capacity for fertilization $[25,26]$.

Overall, the production of $4 \mathrm{HNE}$ has been shown to have a direct effect on the function of its protein targets, leading to cellular damage in the male germline as well as other cell types. Therefore, targeting the lipoxygenases responsible for the production of these reactive aldehydes may be an important strategy to both counter the onset of oxidative stress and reduce the cellular damage generated by 4 HNE. Here, we investigate in more detail the involvement of lipoxygenase proteins in the enzymatic production of $4 \mathrm{HNE}$.

\section{Mechanisms for the Generation of 4HNE: A Focus on Lipoxygenase Proteins}

Lipoxygenase proteins are a highly conserved family of enzymes that are ubiquitously found in plants [35,36], fungi [37] and mammals [38], but are rarely found in lower eukaryotes and prokaryotes and are absent in archaea and viruses [38-40]. Mammalian lipoxygenases typically consist of singular polypeptide chains, two functional domains and a molecular mass of $\sim 75-80 \mathrm{kDa}$ [41-43]. The C terminus contains the catalytic domain, while the $\mathrm{N}$ terminus is involved in processes governing membrane binding and interaction with substrates [42]. The catalytic pocket of the enzyme coordinates a single, non-heme containing iron atom per molecule [41,44], which is actively involved in the redox reactions necessary to facilitate the selective peroxidation of PUFAs [41,45]. However, this two domain structure is not conserved across all prokaryotes [46], and the presence of manganese replaces iron in the catalytic site of some fungal lipoxygenases [47-49]. The classification system of lipoxygenases (ALOX-n) defines the carbon position where oxygenation takes place along the PUFA chain. Table 1 indicates the known paralogs of human lipoxygenases, their substrates and metabolic products.

PUFA substrates for ALOX15 include $\omega-6$ fatty acids such as arachidonic and linoleic acid and the $\omega-3$ fatty acid, docosahexaenoic acid [50]. The mechanisms underpinning lipoxygenase function 
are still not entirely understood. However, it is clear that the iron center can alternate between ferric ( $\mathrm{Fe}^{3+} /$ active) and ferrous ( $\mathrm{Fe}^{2+} /$ inactive) forms [43] and this redox activity assists in hydrogen abstraction $(\mathrm{L}-\mathrm{H} \rightarrow \mathrm{L})$ of PUFAs when the iron atom undergoes a reduction $\left(\mathrm{Fe}^{3+} \rightarrow \mathrm{Fe}^{2+}\right)[41,51]$. This reaction mechanism anticipates that the enzyme is converted back to its active form through oxidation of the iron center $\left(\mathrm{Fe}^{2+} \rightarrow \mathrm{Fe}^{3+}\right)$ and oxygenation $(\mathrm{L} \rightarrow \mathrm{LOO})$ of the PUFA [41,43]. Importantly, recent studies assessing the enzymatic action of ALOX15 have identified binding sites for allosteric inhibition, which will allow for further insight into its specific activity $[52,53]$.

Table 1. Paralogs and metabolites of the family of human lipoxygenase enzymes.

\begin{tabular}{|c|c|c|c|}
\hline Lipoxygenase Enzyme ${ }^{1}$ & Substrates $^{2}$ & Metabolic Products & References \\
\hline ALOX5 & AA LA EPA & 5-HpETE, 5-HETE and DGLA, Leukotrienes & {$[43,54]$} \\
\hline ALOX12 & AA LA EPA DGLA & 12-HpETE, 12-HETE, 12-HPETre, 12-HEPE, 12-HPOTrE & {$[50,54,55]$} \\
\hline ALOX12B & AA LA LwHC & 12R-HpETE, 12R-HETE, 9R-HpODE, 9HwHC & {$[50,54,58]$} \\
\hline ALOX15B & AA & 15-HрETE, 15-HETE & {$[50,54,59]$} \\
\hline
\end{tabular}

1,2 Paralogs of the lipoxygenase family are shown along with their corresponding substrates of arachidonic acid (AA, red), linoleic acid (LA, green), eicosapentanoic acid (EPA) and docosahexaenoic acid (DHA). Abbreviations: arachidonate lipoxygenase (ALOX), epidermal type lipoxygenase (ALOXE), hydroperoxyeicosatetraenoic acid (HpETE), hydroxyeicosatetraenoic acid (HETE), 12-hydroxyeicosapentaenoic acid (HEPE), Hydroperoxyeicosatrienoic acid (HPEtrE) hydroperoxyoctadecadienoic (HpODE), hydroxyoctadecadienoic (HODE), 12-hydroperoxy-9Z,13E,15-octadecatrienoic acid (12-HPOTrE) hydroperoxydocosahexaenoic acid (HpDHA) and Dihomo- $\gamma$-linoleic acid (DGLA), Linoleyl- $\omega$-hydroxy ceramide (L $\omega \mathrm{HC}), 9$ (R)-hydroperoxyllinoleoyl- $\omega$-hydroxy

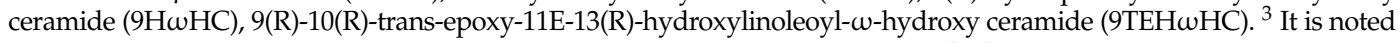
that under normoxic conditions ALOXE3 does not exhibit lipoxygenase activity [60].

Numerous studies have focused on the possible pathogenic implications of the lipoxygenase family, with a key focus on ALOX5 due to its role in the biosynthesis of leukotrienes, which are inflammatory mediators [61]. Leukotrienes can cause pathological inflammatory responses in diseases such as cystic fibrosis [62], inflammatory bowel disease [63] and asthma [64], thereby presenting a relationship between lipoxygenase activity and immune responses. Chronic inflammation has the potential to place cells under stress, which in turn can promote cell death or abnormal cell differentiation [65]; the latter of these, in turn, has the potential to promote tumorigenesis [66]. In the case of ALOX15, several studies have implicated this protein in the inflammation pathway of diseases such as colorectal cancer [67], prostate cancer [68] and chronic myeloid leukemia [69]. However, while the formation of 14,15-leukotrienes from ALOX15 has been proposed [70], the biological relevance of these specific compounds has not yet been explored.

Interestingly, ALOX15 activity has also been linked to obesity as the enzyme is highly expressed in omental tissue compared to the subcutaneous fat layer of obese patients [71]. Accordingly, analysis of ALOX15 transgenic mice supports a link between inflammation, obesity and insulin resistance [72]. Indeed, this study proposes that an overexpression of ALOX15 stimulates the production of pro-inflammatory mediators, which promote insulin resistance induced through a high fat diet [72]. In turn, insulin resistance results in an overall increased risk in developing type 2 diabetes and obesity [72]. It is now well established that obesity can have detrimental impacts on both maternal and paternal fertility, as well as embryo health and development [73,74]. Obesity in males, is linked with an increased time to conception and a decrease in sperm function [73]. With these lines of evidence, the activity of ALOX15 may have a systemic and indirect effect on male infertility through obesity, alongside the direct effects it may have within the male germline through 4 HNE production. The imperative for understanding mechanisms of male infertility is further supported by the growing evidence that male fertility status may in fact be an effective indicator of general health of the individual [75-77]. Specifically, studies assessing the fertility of more than 40,000 males have revealed that important semen parameters such as volume, cell count, and morphology are directly correlated 
with life expectancy [76]. A similar link has also been observed in the context of the prevalence of infertility in diseased men experiencing inflammatory bowel disease [78], obesity [79-81], diabetes [82], hypertension and also sexually transmitted diseases such as chlamydia [83], human immunodeficiency virus (HIV), and hepatitis C [84]. Such data suggest that drivers of poor fertility may originate in systemic issues rather than being restricted to the male reproductive tract, again emphasizing the importance of gaining a better understanding of the fundamental aspects of infertility and its origins.

At this time, literature on ALOX15 in the male germline is very scarce. Nevertheless, analysis of ALOX15 within mature spermatozoa has indicated a putative role for the enzyme within the cytoplasmic droplet of mammalian species such as boar [85] and mouse [86]. These studies suggest that ALOX15 works in concert with the ubiquitin pathway to cause organelle degradation, assisting in the removal of the cytoplasmic droplet [85]. Additionally, the production of an ALOX15 knockout mouse model has shown that the loss of this enzyme does not compromise sperm production per se. However, the spermatozoa produced from null males exhibited atypical cytoplasmic droplet degradation during epididymal transit [85]. Earlier work provided an indication that the bull sperm acrosome reaction may be suppressed following lipoxygenase inhibition [87]. However, these data must be interpreted with caution owing to the use of non-specific lipoxygenase inhibitors, and the absence of substantiating evidence to illuminate the direct role of ALOX15 in the induction of acrosomal exocytosis. Recent studies have suggested a possible link between this lipoxygenase enzyme and oxidative stress propagation in human spermatozoa [88] and in mouse germ cells [89,90]. Using an immortalized spermatocyte cell line [GC-2spd(ts)], we have demonstrated that the treatment of these cells with an ALOX15 inhibitor resulted in significant reductions in 4HNE protein modifications and subsequent oxidative stress cascades [89]. However, direct evidence of the ability of PD146176 to inhibit ALOX15 function is yet to be established and further work is required to verify the function of ALOX15 in rodent models [91]. Despite these shortcomings, using a double knockout study, Brütsch and colleagues have established a clear link between ALOX15 activity and a key antioxidant, glutathione peroxidase 4 (GPX4), in mouse germ cells [90]. In this study, the inactivation of Gpx4 (genotype $\mathrm{Gpx}^{+/-}$) led to significant sperm defects, including marked reductions in sperm motility (total, rapid and progressive). These $\mathrm{Gx}^{+/-}$mice correspondingly exhibited significantly reduced litter sizes compared to wild type mice. However, both the motility attributes and the litter sizes of the animals were significantly improved following a simultaneous knockout of the Alox 15 gene (i.e., genotype $\mathrm{Gp} 4^{+-}{ }^{-} / \mathrm{Alo} \times 15^{-/-}$), thus implicating ALOX15 in the mediation of oxidative damage in the mouse [90].

In addition to these animal studies, we have recently reported on a possible role for ALOX15 in human spermatozoa using the selective ALOX15 inhibitor 6,11-dihydro[1]benzothiopyrano[4,3-b]indole (PD146176, Tocris). This (PD146176) inhibits ALOX15 through non-competitive and non-antioxidant means [92,93] and has previously been shown to reduce the production of specific ALOX15 metabolites such as 15-HPETE [94] and 13-HODE [95]. Though minimal studies have used PD146176 in spermatozoa, the use of this inhibitor in conjunction with an oxidative challenge has been documented to give rise to significant ROS reductions in neuronal cells [96]. This is consistent with our findings in human spermatozoa, that under oxidative stress conditions ALOX15 inhibition significantly decreased ROS production and lipid peroxidation levels while also improving the functional competence of sperm populations including their motility, acrosome reaction rates and ability to undergo sperm-egg interaction processes [88]. Importantly, such studies are also consistent with those completed in the context of neurological disorders such as Alzheimer's disease, where disease progression often relies on oxidative stress and the production of $4 \mathrm{HNE}$. This lipid peroxide end product has been shown to promote the production of amyloid beta plaques and neuronal death [97-99]. Strikingly, these studies have demonstrated reduced amyloid plaque production with significant improvements in memory deficits through the inclusion of the same ALOX15 inhibitor, PD146176 [100,101]. These data provide further evidence for the use of 
PD146176 as a potential therapeutic means to prevent pathologies induced through oxidative stress and lipid peroxidation.

\section{Protecting the Germline from 4 HNE-Induced Damage}

There are increasing numbers of couples using assisted reproductive technologies (ART) to achieve conception. This has led to more than 5 million births since the invention of this technology [102]. While ART has undoubtedly changed the lives of many, such technologies are highly expensive and have a live birth success rate of no more than $\sim 30 \%[103,104]$. There may also be a level of risk associated with assisted conception where numerous studies have confirmed that higher levels of DNA damage are present in men with subfertility [105]. This presents the possibility that ARTs could be inadvertently using damaged sperm cells which may elevate the risk of adverse health outcomes for the offspring conceived through assisted reproduction [106,107]. Additionally, the lack of selection pressure on the gametes may eventually propagate further fertility issues for future generations. A major origin of sperm cell damage arises through the onset of oxidative stress. Congruent with DNA fragmentation, markers of oxidative stress are also elevated in the infertile population [108]. It is therefore without surprise that antioxidant supplementation is an extensively studied area for the mitigation of male infertility. Table 2 summarizes numerous studies that have examined male fertility following antioxidant supplementation and their corresponding reproductive outcome. This table was collated through examination of external literature as well as analysis of a variety of detailed reviews [109-111]. Interestingly, only 5 out of the 28 investigated studies presented improvements to pregnancy and live birth rates following antioxidant supplementation, with positive effects associated with astaxanthin [112], L-carnitine + L-acetyl carnitine [113], Menevit ${ }^{\circledR}$ [114], vitamin E [115] and zinc sulphate [116]. While some studies observed very high levels of variability when measuring semen parameters, the studies focusing on L-glutathione, lycopene, $\mathrm{N}$-acetylcysteine + selenium, ubiquinone, selenium and zinc sulphate, consistently presented improvements in at least one or more semen parameter [116-122]. Other studies using antioxidants such as Co-enzyme Q10, folic acid + zinc sulphate, lycopene and L-carnitine + L-acetyl carnitine showed variation in effects between trials, with some studies reporting improvements to semen parameters [113,118,123-128], while others showing no positive effects [129-131]. Some of this variation may be attributed to intrinsic variations within each trial, such as dose regimes, methodology and the duration of treatments. Nonetheless, this variability, combined with a lack of clinical success in terms of increased pregnancy rates and live birth rates, highlights a clear need for further investigation into effective alternative strategies to prevent, or at least limit, ROS production in the male germline to improve a large subset of male fertility issues.

In seeking to account for the lack of consistent clinical success using regimens based on single antioxidant supplementation as a means for combating male infertility, it is possible that the scavenging nature of antioxidants [132] fails to provide direct protection against the cascades of lipid peroxidation and $4 \mathrm{HNE}$ production that ensue under conditions of oxidative stress. Interestingly, nucleophiles such as penicillamine have been shown to successfully reduce cellular ROS in both human spermatozoa and in oocytes $[19,25,133,134]$; effects that manifest in the recovery of sperm-oocyte interaction in vitro [25]. However, this antioxidant has serious off-target toxicity concerns [135], and thus investigation into the clinical utility of penicillamine is not possible. Another novel antioxidant formulation therapy in the male germline is Fertilix ${ }^{\circledR}$ (Cell Oxess, Ewing, USA), which has been shown to protect against DNA damage in antioxidant deficient mice [136]. However, clinical trials have yet to be performed to establish whether this therapy is an appropriate method for treating infertile men. Among alternative methods that have shown promise in protecting somatic cells from diseases linked to lipid peroxidation-dependent mechanisms [137-139], is the stabilization of the lipid membrane through deuteration [140]. Such success provides an important precedent to investigate the efficacy of this strategy to protect sperm membranes. 
Table 2. Benefits of antioxidant supplementation for male fertility. A summary of tested antioxidants and their relative success for the improvement of male fertility as reviewed by Ahmadi et al., Ross et al., and Majzoub and Agarwal [109-111].

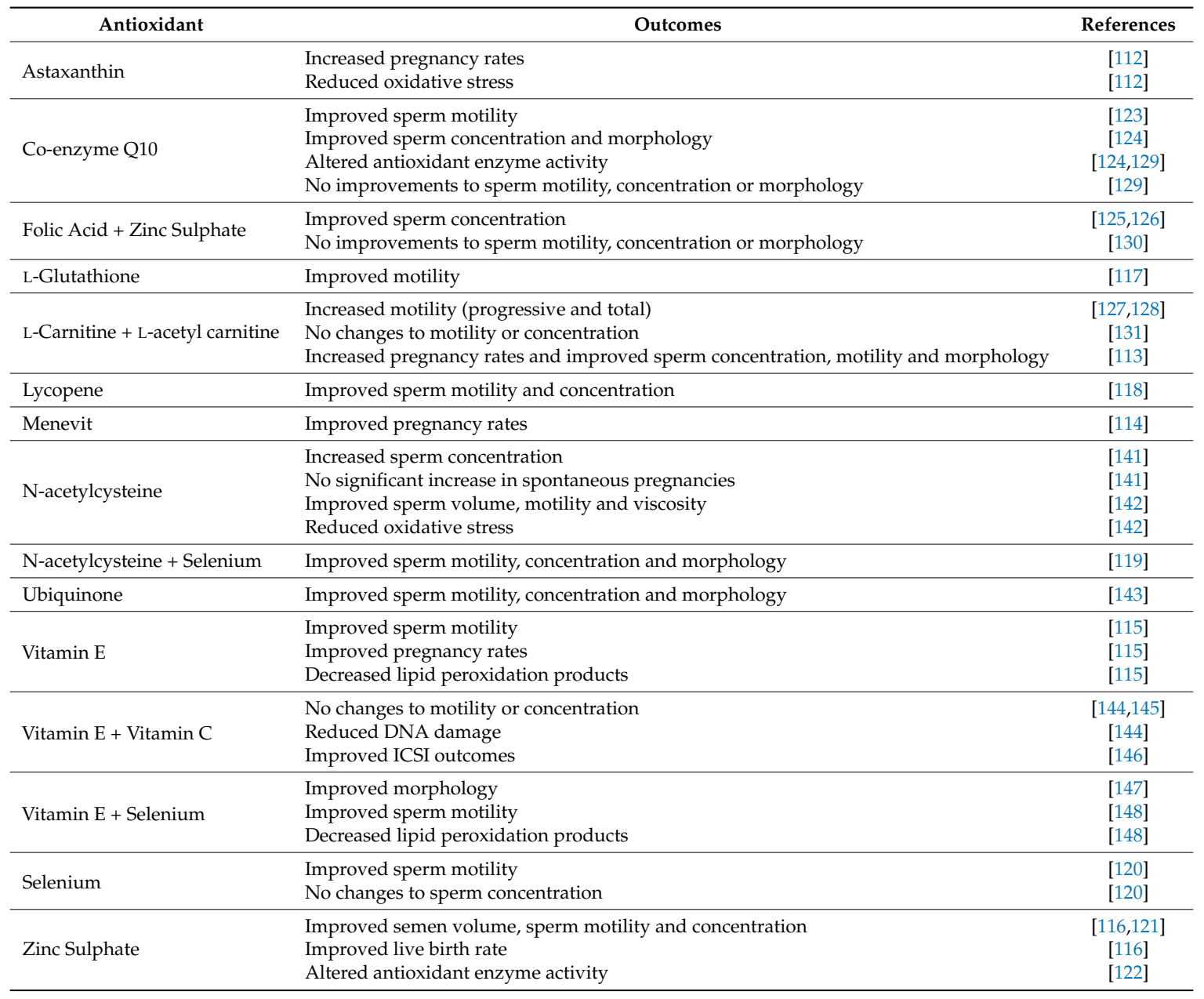

\section{Conclusions}

In this review we discuss strategies to alleviate oxidative stress in males suffering from fertility issues (summarized in Figure 2). Here we provide new perspectives on the lipoxygenase-lipid peroxidation pathway and discuss the merit of ALOX15 as a potential therapeutic target that could be exploited to protect human spermatozoa against oxidative stress, a key origin of poor cell function. Overall, this review highlights the importance of correct lipid metabolism in the maintenance of sperm function and fertility and provides the impetus to explore targeted, lipid-based antioxidant approaches to prevent lipid-peroxidation induced changes in the male germline. 


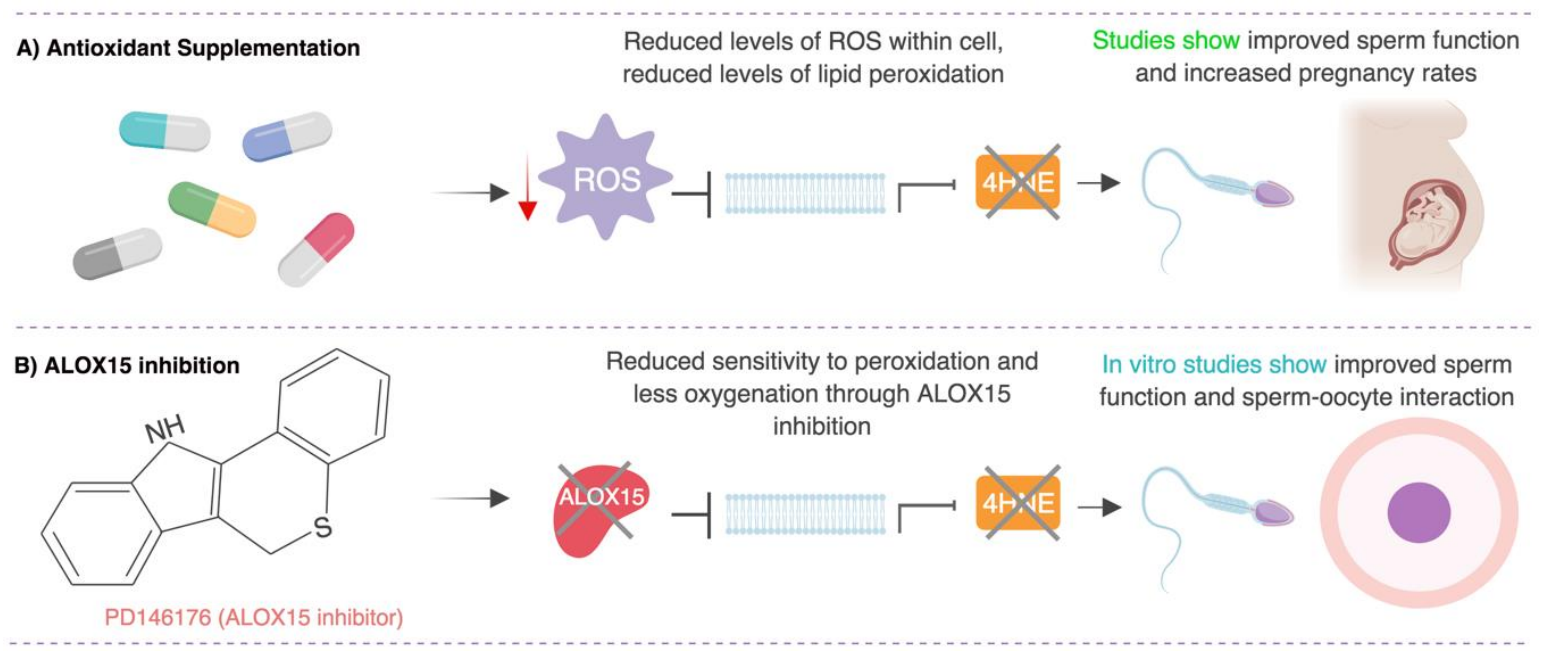

Figure 2. Potential strategies to protect human spermatozoa against oxidative stress. This model explores two strategies to protect against oxidative stress: antioxidant supplementation and arachidonate 15-lipoxygenase (ALOX15) inhibition. (A) Antioxidant supplementation has been shown to reduce levels of ROS, hence lipid peroxidation may be prevented, or its products scavenged, allowing sperm function to be improved. (B) ALOX15 inhibition in human sperm has been demonstrated to reduce lipid peroxidation and improve sperm function and sperm-oocyte interaction in vitro. Figure created with BioRender.

Author Contributions: J.L.H.W., G.N.D.I., B.N. and E.G.B. contributed to this review as follows; conceptualization, J.L.H.W. and E.G.B.; Investigation and data curation, J.L.H.W.; Writing-original draft preparation, J.L.H.W.; Writing-Review and editing, E.G.B., B.N. and G.N.D.; Funding acquisition, B.N. Project Administration, B.N., G.N.D.I. and E.G.B.

Funding: This study was funded through an NHMRC CJ Martin Fellowship (APP1138701) to E.G.B. and an NHMRC Project Grant (APP1101953) to B.N. J.L.H.W. is the recipient of an Australian Government Research Training Program (RTP) PhD Scholarship.

Conflicts of Interest: The authors declare that there is no conflict of interest.

\section{References}

1. Trussell, J. Optimal diagnosis and medical treatment of male infertility. Semin. Reprod. Med. 2013, 31, 235-236. [CrossRef] [PubMed]

2. Kumar, N.; Singh, A.K. Trends of male factor infertility, an important cause of infertility: A review of literature. J. Hum. Reprod. Sci. 2015, 8, 191-196. [CrossRef] [PubMed]

3. Liu, D.; Baker, H. Defective sperm-zona pellucida interaction: A major cause of failure of fertilization in clinical in-vitro fertilization. Hum. Reprod. 2000, 15, 702-708. [CrossRef] [PubMed]

4. Guthrie, H.; Welch, G. Effects of reactive oxygen species on sperm function. Theriogenology 2012, 78, 1700-1708. [CrossRef] [PubMed]

5. Aitken, R.J.; Baker, M.A.; Nixon, B. Are sperm capacitation and apoptosis the opposite ends of a continuum driven by oxidative stress? Asian J. Androl. 2015, 17, 633-639. [CrossRef] [PubMed]

6. Bayr, H. Reactive oxygen species. Crit. Care Med. 2005, 33, S498-S501. [CrossRef]

7. Aitken, J.R.; Nixon, B. Sperm capacitation: A distant landscape glimpsed but unexplored. Mol. Hum. Reprod. 2013, 19, 785-793. [CrossRef] [PubMed]

8. O'Flaherty, C.; Beorlegui, N.; Beconi, M. Reactive oxygen species requirements for bovine sperm capacitation and acrosome reaction. Theriogenology 1999, 52, 289-301. [CrossRef]

9. Aitken, R.J.; Gordon, E.; Harkiss, D.; Twigg, J.P.; Milne, P.; Jennings, Z.; Irvine, D.S. Relative impact of oxidative stress on the functional competence and genomic integrity of human spermatozoa. Biol. Reprod. 1998, 59, 1037-1046. [CrossRef] [PubMed]

10. Aitken, R.J.; Clarkson, J.S.; Fishel, S. Generation of reactive oxygen species, lipid peroxidation, and human sperm function. Biol. Reprod. 1989, 41, 183-197. [CrossRef] [PubMed] 
11. Marnett, L.J. Oxy radicals, lipid peroxidation and DNA damage. Toxicology 2002, 181, 219-222. [CrossRef]

12. Chaves, F.J.; Mansego, M.L.; Blesa, S.; Gonzalez-Albert, V.; Jiménez, J.; Tormos, M.C.; Espinosa, O.; Giner, V.; Iradi, A.; Saez, G.; et al. Inadequate cytoplasmic antioxidant enzymes response contributes to the oxidative stress in human hypertension. Am. J. Hypertens. 2007, 20, 62-69. [CrossRef] [PubMed]

13. Birben, E.; Sahiner, U.M.; Sackesen, C.; Erzurum, S.; Kalayci, O. Oxidative stress and antioxidant defense. World Allergy Organ. J. 2012, 5, 9. [CrossRef] [PubMed]

14. Fischer, M.A.; Willis, J.; Zini, A. Human sperm DNA integrity: Correlation with sperm cytoplasmic droplets. Urology 2003, 61, 207-211. [CrossRef]

15. Cooper, T.G.; Yeung, C.H.; Fetic, S.; Sobhani, A.; Nieschlag, E. Cytoplasmic droplets are normal structures of human sperm but are not well preserved by routine procedures for assessing sperm morphology. Hum. Reprod. 2004, 19, 2283-2288. [CrossRef] [PubMed]

16. Sabeti, P.; Pourmasumi, S.; Rahiminia, T.; Akyash, F.; Talebi, A.R. Etiologies of sperm oxidative stress. Int. J. Reprod. Biomed. 2016, 14, 231-240. [CrossRef]

17. Lenzi, A.; Picardo, M.; Gandini, L.; Dondero, F. Lipids of the sperm plasma membrane: From polyunsaturated fatty acids considered as markers of sperm function to possible scavenger therapy. Hum. Reprod. Update 1996, 2, 246-256. [CrossRef] [PubMed]

18. Sanocka, D.; Kurpisz, M. Reactive oxygen species and sperm cells. Reprod. Biol. Endocrinol. $2004,2,12$. [CrossRef] [PubMed]

19. Aitken, R.J.; Whiting, S.; De Iuliis, G.N.; McClymont, S.; Mitchell, L.A.; Baker, M.A. Electrophilic aldehydes generated by sperm metabolism activate mitochondrial reactive oxygen species generation and apoptosis by targeting succinate dehydrogenase. J. Biol. Chem. 2012, 287, 33048-33060. [CrossRef] [PubMed]

20. Ayala, A.; Muñoz, M.F.; Argüelles, S. Lipid peroxidation: Production, metabolism, and signaling mechanisms of malondialdehyde and 4-hydroxy-2-nonenal. Oxid. Med. Cell. Longev. 2014, 2014, 360438. [CrossRef] [PubMed]

21. Pizzimenti, S.; Ciamporcero, E.S.; Daga, M.; Pettazzoni, P.; Arcaro, A.; Cetrangolo, G.; Minelli, R.; Dianzani, C.; Lepore, A.; Gentile, F.; et al. Interaction of aldehydes derived from lipid peroxidation and membrane proteins. Front. Physiol. 2013, 4, 242. [CrossRef] [PubMed]

22. Moazamian, R.; Polhemus, A.; Connaughton, H.; Fraser, B.; Whiting, S.; Gharagozloo, P.; Aitken, R.J. Oxidative stress and human spermatozoa: Diagnostic and functional significance of aldehydes generated as a result of lipid peroxidation. Mol. Hum. Reprod. 2015, 21, 502-515. [CrossRef] [PubMed]

23. Hsieh, Y.-Y.; Chang, C.-C.; Lin, C.-S. Seminal malondialdehyde concentration but not glutathione peroxidase activity is negatively correlated with seminal concentration and motility. Int. J. Biol. Sci. 2006, 2, $23-29$. [CrossRef] [PubMed]

24. Mehrotra, A.; Katiyar, D.K.; Agarwal, A.; Das, V.; Pant, K.K. Role of total antioxidant capacity and lipid peroxidation in fertile and infertile men. Biomed. Res. 2013, 24, 347-352.

25. Bromfield, E.G.; Aitken, R.J.; Anderson, A.L.; McLaughlin, E.A.; Nixon, B. The impact of oxidative stress on chaperone-mediated human sperm-egg interaction. Hum. Reprod. 2015, 30, 2597-2613. [CrossRef] [PubMed]

26. Aitken, R.J.; Gibb, Z.; Mitchell, L.A.; Lambourne, S.R.; Connaughton, H.S.; De Iuliis, G.N. Sperm motility is lost in vitro as a consequence of mitochondrial free radical production and the generation of electrophilic aldehydes but can be significantly rescued by the presence of nucleophilic thiols. Biol. Reprod. 2012, 87, 110. [CrossRef] [PubMed]

27. Spiteller, G. Is lipid peroxidation of polyunsaturated acids the only source of free radicals that induce aging and age-related diseases? Rejuv. Res. 2010, 13, 91-103. [CrossRef] [PubMed]

28. Schneider, C.; Tallman, K.A.; Porter, N.A.; Brash, A.R. Two distinct pathways of formation of 4-hydroxynonenal mechanisms of nonenzymatic transformation of the 9-and 13-hydroperoxides of linoleic acid to 4-hydroxyalkenals. J. Biol. Chem. 2001, 276, 20831-20838. [CrossRef] [PubMed]

29. Morisaki, N.; Lindsey, J.A.; Stitts, J.M.; Zhang, H.; Cornwell, D.G. Fatty acid metabolism and cell proliferation. V. Evaluation of pathways for the generation of lipid peroxides. Lipids 1984, 19, 381-394. [CrossRef] [PubMed]

30. Shoeb, M.; Naseem, H.A.; Satish, K.S.; Kota, V.R. 4-Hydroxynonenal in the pathogenesis and progression of human diseases. Curr. Med. Chem. 2014, 21, 230-237. [CrossRef] [PubMed]

31. Aitken, R.J.; Koppers, A.J. Apoptosis and DNA damage in human spermatozoa. Asian J. Androl. 2011, 13, 36-42. [CrossRef] [PubMed] 
32. Rauniyar, N.; Prokai, L. Detection and identification of 4-hydroxy-2-nonenal Schiff-base adducts along with products of Michael addition using data-dependent neutral loss-driven MS3 acquisition: Method evaluation through an in vitro study on cytochrome c oxidase modifications. Proteomics 2009, 9, 5188-5193. [CrossRef] [PubMed]

33. Doorn, J.A.; Petersen, D.R. Covalent modification of amino acid nucleophiles by the lipid peroxidation products 4-hydroxy-2-nonenal and 4-oxo-2-nonenal. Chem. Res. Toxicol. 2002, 15, 1445-1450. [CrossRef] [PubMed]

34. Redgrove, K.A.; Nixon, B.; Baker, M.A.; Hetherington, L.; Baker, G.; Liu, D.Y.; Aitken, R.J. The molecular chaperone HSPA2 plays a key role in regulating the expression of sperm surface receptors that mediate sperm-egg recognition. PLoS ONE 2012, 7, e50851. [CrossRef] [PubMed]

35. Grechkin, A. Recent developments in biochemistry of the plant lipoxygenase pathway. Prog. Lipid Res. 1998, 37, 317-352. [CrossRef]

36. Shibata, D.; Axelrod, B. Plant lipoxygenases. J. Lipid Med. Cell Signal. 1995, 12, 213-228. [CrossRef]

37. Heshof, R.; Jylhä, S.; Haarmann, T.; Jørgensen, A.L.; Dalsgaard, T.K.; de Graaff, L.H. A novel class of fungal lipoxygenases. Appl. Microbiol. Biotechnol. 2014, 98, 1261-1270. [CrossRef] [PubMed]

38. Horn, T.; Adel, S.; Schumann, R.; Sur, S.; Kakularam, K.R.; Polamarasetty, A.; Redanna, P.; Kuhn, H.; Heydeck, D. Evolutionary aspects of lipoxygenases and genetic diversity of human leukotriene signaling. Prog. Lipid Res. 2015, 57, 13-39. [CrossRef] [PubMed]

39. Vance, R.E.; Hong, S.; Gronert, K.; Serhan, C.N.; Mekalanos, J.J. The opportunistic pathogen Pseudomonas aeruginosa carries a secretable arachidonate 15-lipoxygenase. Proc. Natl. Acad. Sci. USA 2004, 101, 2135-2139. [CrossRef] [PubMed]

40. Hansen, J.; Garreta, A.; Benincasa, M.; Fusté, M.C.; Busquets, M.; Manresa, A. Bacterial lipoxygenases, a new subfamily of enzymes? A phylogenetic approach. Appl. Microbiol. Biotechnol. 2013, 97, 4737-4747. [CrossRef] [PubMed]

41. Ivanov, I.; Kuhn, H.; Heydeck, D. Structural and functional biology of arachidonic acid 15-lipoxygenase-1 (ALOX15). Gene 2015, 573, 1-32. [CrossRef] [PubMed]

42. Kuhn, H.; Banthiya, S.; van Leyen, K. Mammalian lipoxygenases and their biological relevance. Biochim. Biophys. Acta (BBA)-Mol. Cell Biol. Lipids 2015, 1851, 308-330. [CrossRef] [PubMed]

43. Brash, A.R. Lipoxygenases: Occurrence, functions, catalysis, and acquisition of substrate. J. Biol. Chem. 1999, 274, 23679-23682. [CrossRef] [PubMed]

44. Chasteen, N.D.; Grady, J.K.; Skorey, K.I.; Neden, K.J.; Riendeau, D.; Percival, M.D. Characterization of the non-heme iron center of human 5-lipoxygenase by electron paramagnetic resonance, fluorescence, and ultraviolet-visible spectroscopy: Redox cycling between ferrous and ferric states. Biochemistry 1993, 32, 9763-9771. [CrossRef] [PubMed]

45. Feussner, I.; Wasternack, C. The lipoxygenase pathway. Ann. Rev. Plant Biol. 2002, 53, 275-297. [CrossRef] [PubMed]

46. Garreta, A.; Val-Moraes, S.P.; García-Fernández, Q.; Busquets, M.; Juan, C.; Oliver, A.; Ortiz, A.; Gaffney, B.J.; Fita, I.; Manresa, À.; et al. Structure and interaction with phospholipids of a prokaryotic lipoxygenase from Pseudomonas aeruginosa. FASEB J. 2013, 27, 4811-4821. [CrossRef] [PubMed]

47. Wennman, A.; Oliw, E.H.; Karkehabadi, S.; Chen, Y. Crystal structure of manganese lipoxygenase of the rice blast fungus Magnaporthe oryzae. J. Biol. Chem. 2016. [CrossRef] [PubMed]

48. Wennman, A.; Jernerén, F.; Magnuson, A.; Oliw, E.H. Expression and characterization of manganese lipoxygenase of the rice blast fungus reveals prominent sequential lipoxygenation of $\alpha$-linolenic acid. Arch. Biochem. Biophys. 2015, 583, 87-95. [CrossRef] [PubMed]

49. Su, C.; Oliw, E.H. Manganese lipoxygenase purification and characterization. J. Biol. Chem. 1998, 273, 13072-13079. [CrossRef] [PubMed]

50. Dobrian, A.D.; Lieb, D.C.; Cole, B.K.; Taylor-Fishwick, D.A.; Chakrabarti, S.K.; Nadler, J.L. Functional and pathological roles of the 12-and 15-lipoxygenases. Prog. Lipid Res. 2011, 50, 115-131. [CrossRef] [PubMed]

51. Ivanov, I.; Heydeck, D.; Hofheinz, K.; Roffeis, J.; O’Donnell, V.B.; Kuhn, H.; Walther, M. Molecular enzymology of lipoxygenases. Arch. Biochem. Biophys. 2010, 503, 161-174. [CrossRef] [PubMed]

52. Meng, H.; Dai, Z.; Zhang, W.; Liu, Y.; Lai, L. Molecular mechanism of 15-lipoxygenase allosteric activation and inhibition. Phys. Chem. Chem. Phys. 2018, 20, 14785-14795. [CrossRef] [PubMed] 
53. Meng, H.; McClendon, C.L.; Dai, Z.; Li, K.; Zhang, X.; He, S.; Shang, E.; Liu, Y.; Lai, L. Discovery of novel 15-lipoxygenase activators to shift the human arachidonic acid metabolic network toward inflammation resolution. J. Med. Chem. 2015, 59, 4202-4209. [CrossRef] [PubMed]

54. Wisastra, R.; Dekker, F.J. Inflammation, cancer and oxidative lipoxygenase activity are intimately linked. Cancers 2014, 6, 1500-1521. [CrossRef] [PubMed]

55. Tersey, S.A.; Bolanis, E.; Holman, T.R.; Maloney, D.J.; Nadler, J.L.; Mirmira, R.G. Minireview: 12-lipoxygenase and islet $\beta$-cell dysfunction in diabetes. Mol. Endocrinol. 2015, 29, 791-800. [CrossRef] [PubMed]

56. Vangaveti, V.; Baune, B.T.; Kennedy, R.L. Hydroxyoctadecadienoic acids: Novel regulators of macrophage differentiation and atherogenesis. Ther. Adv. Endocrinol. MeTable 2010, 1, 51-60. [CrossRef] [PubMed]

57. Chang, J.; Jiang, L.; Wang, Y.; Yao, B.; Yang, S.; Zhang, B.; Zhang, M.Z. 12/15 lipoxygenase regulation of colorectal tumorigenesis is determined by the relative tumor levels of its metabolite 12-HETE and 13-HODE in animal models. Oncotarget 2015, 6, 2879. [CrossRef] [PubMed]

58. Muñoz-Garcia, A.; Thomas, C.P.; Keeney, D.S.; Zheng, Y.; Brash, A.R. The importance of the lipoxygenase-hepoxilin pathway in the mammalian epidermal barrier. Biochim. Biophys. Acta (BBA)-Mol. Cell Biol. Lipids 2014, 1841, 401-408. [CrossRef] [PubMed]

59. Brash, A.R.; Boeglin, W.E.; Chang, M.S. Discovery of a second 15S-lipoxygenase in humans. Proc. Natl. Acad. Sci. USA 1997, 94, 6148-6152. [CrossRef] [PubMed]

60. Yu, Z.; Schneider, C.; Boeglin, W.E.; Marnett, L.J.; Brash, A.R. The lipoxygenase gene ALOXE3 implicated in skin differentiation encodes a hydroperoxide isomerase. Proc. Natl. Acad. Sci. USA 2003, 100, 9162-9167. [CrossRef] [PubMed]

61. Haeggstrom, J.Z.; Funk, C.D. Lipoxygenase and leukotriene pathways: Biochemistry, biology, and roles in disease. Chem. Rev. 2011, 111, 5866-5898. [CrossRef] [PubMed]

62. Lawrence, R.; Sorrell, T. Eicosapentaenoic acid in cystic fibrosis: Evidence of a pathogenetic role for leukotriene B. 4. Lancet 1993, 342, 465-469. [CrossRef]

63. Sharon, P.; Stenson, W.F. Enhanced Synthesis of Leukotriene B4 by Colonic Mucosa in Inflammatory Bowel. Gastroenterology 1984, 86, 453-460. [PubMed]

64. O'Byrne, P.M. Leukotrienes in the pathogenesis of asthma. Chest J. 1997, 111, 27S-34S. [CrossRef]

65. Rock, K.L.; Kono, H. The inflammatory response to cell death. Ann. Rev. Pathol. 2008, 3, 99-126. [CrossRef] [PubMed]

66. Okada, F. Inflammation-related carcinogenesis: Current findings in epidemiological trends, causes and mechanisms. Yonago Acta Med. 2014, 57, 65-72. [PubMed]

67. Mao, F.; Wang, M.; Wang, J.; Xu, W.R. The role of 15-LOX-1 in colitis and colitis-associated colorectal cancer. Inflamm. Res. 2015, 64, 661-669. [CrossRef] [PubMed]

68. Kelavkar, U.P.; Harya, N.S.; Hutzley, J.; Bacich, D.J.; Monzon, F.A.; Chandran, U.; Dhir, R.; O’Keefe, D.S. DNA methylation paradigm shift: 15-lipoxygenase-1 upregulation in prostatic intraepithelial neoplasia and prostate cancer by atypical promoter hypermethylation. Prostaglandins Other Lipid Med. 2007, 82, 185-197. [CrossRef] [PubMed]

69. Chen, Y.; Peng, C.; Abraham, S.A.; Shan, Y.; Guo, Z.; Desouza, N.; Cheloni, G.; Li, D.; Holyoake, T.L.; Li, S. Arachidonate 15-lipoxygenase is required for chronic myeloid leukemia stem cell survival. J. Clin. Investig. 2014, 124, 3847-3862. [CrossRef] [PubMed]

70. Bryant, R.W.; Schewe, T.; Rapoport, S.M.; Bailey, J.M. Leukotriene formation by a purified reticulocyte lipoxygenase enzyme. Conversion of arachidonic acid and 15-hydroperoxyeicosatetraenoic acid to 14, 15-leukotriene A4. J. Biol. Chem. 1985, 260, 3548-3555. [PubMed]

71. Dobrian, A.D.; Lieb, D.C.; Ma, Q.; Lindsay, J.W.; Cole, B.K.; Ma, K.; Chakrabarti, S.K.; Kuhn, N.S.; Wohlgemuth, S.D.; Fontana, M.; et al. Differential expression and localization of 12/15 lipoxygenases in adipose tissue in human obese subjects. Biochem. Biophys. Res. Commun. 2010, 403, 485-490. [CrossRef] [PubMed]

72. Sears, D.D.; Miles, P.D.; Chapman, J.; Ofrecio, J.M.; Almazan, F.; Thapar, D.; Miller, Y.I. 12/15-lipoxygenase is required for the early onset of high fat diet-induced adipose tissue inflammation and insulin resistance in mice. PLoS ONE 2009, 4, e7250. [CrossRef] [PubMed]

73. Palmer, N.O.; Bakos, H.W.; Fullston, T.; Lane, M. Impact of obesity on male fertility, sperm function and molecular composition. Spermatogenesis 2012, 2, 253-263. [CrossRef] [PubMed]

74. Leddy, M.A.; Power, M.L.; Schulkin, J. The impact of maternal obesity on maternal and fetal health. Rev. Obstet. Gynecol. 2008, 1, 170-178. [PubMed] 
75. Eisenberg, M.L.; Li, S.; Behr, B.; Cullen, M.R.; Galusha, D.; Lamb, D.J.; Lipshultz, L.I. Semen quality, infertility and mortality in the USA. Hum. Reprod. 2014, 29, 1567-1574. [CrossRef] [PubMed]

76. Jensen, T.K.; Jacobsen, R.; Christensen, K.; Nielsen, N.C.; Bostofte, E. Good Semen Quality and Life Expectancy: A Cohort Study of 43,277 Men. Am. J. Epidemiol. 2009, 170, 559-565. [CrossRef] [PubMed]

77. Eisenberg, M.L.; Li, S.; Behr, B.; Pera, R.R.; Cullen, M.R. Relationship between semen production and medical comorbidity. Fertil. Steril. 2015, 103, 66-71. [CrossRef] [PubMed]

78. Rossato, M.; Foresta, C. Antisperm antibodies in inflammatory bowel disease. Arch. Intern. Med. 2004, 164, 2281-2283. [CrossRef] [PubMed]

79. Sallmén, M.; Sandler, D.P.; Hoppin, J.A.; Blair, A.; Baird, D.D. Reduced fertility among overweight and obese men. Epidemiology 2006, 17, 520-523. [CrossRef] [PubMed]

80. Nguyen, R.H.; Wilcox, A.J.; Skjærven, R.; Baird, D.D. Men's body mass index and infertility. Hum. Reprod. 2007, 22, 2488-2493. [CrossRef] [PubMed]

81. Ramlau-Hansen, C.H.; Thulstrup, A.M.; Nohr, E.A.; Bonde, J.P.; Sørensen, T.I.; Olsen, J. Subfecundity in overweight and obese couples. Hum. Reprod. 2007, 22, 1634-1637. [CrossRef] [PubMed]

82. Agbaje, I.M.; Rogers, D.A.; McVicar, C.M.; McClure, N.; Atkinson, A.B.; Mallidis, C.; Lewis, S.E. Insulin dependant diabetes mellitus: Implications for male reproductive function. Hum. Reprod. 2007, 22, 1871-1877. [CrossRef] [PubMed]

83. Mazzoli, S.; Cai, T.; Addonisio, P.; Bechi, A.; Mondaini, N.; Bartoletti, R. Chlamydia trachomatis infection is related to poor semen quality in young prostatitis patients. Eur. Urol. 2010, 57, 708-714. [CrossRef] [PubMed]

84. Lorusso, F.; Palmisano, M.; Chironna, M.; Vacca, M.; Masciandaro, P.; Bassi, E.; Luigi, S.L.; Depalo, R. Impact of chronic viral diseases on semen parameters. Andrologia 2010, 42, 121-126. [CrossRef] [PubMed]

85. Fischer, K.A.; Van Leyen, K.; Lovercamp, K.W.; Manandhar, G.; Sutovsky, M.; Feng, D.; Safranski, T.; Sutovsky, P. 15-Lipoxygenase is a component of the mammalian sperm cytoplasmic droplet. Reproduction 2005, 130, 213-222. [CrossRef] [PubMed]

86. Moore, K.; Lovercamp, K.; Feng, D.; Antelman, J.; Sutovsky, M.; Manandhar, G.; van Leyen, K.; Safranski, T.; Sutovsky, P. Altered epididymal sperm maturation and cytoplasmic droplet migration in subfertile male Alox15 mice. Cell Tissue Res. 2010, 340, 569-581. [CrossRef] [PubMed]

87. Lax, Y.; Grossman, S.; Rubinstein, S.; Magid, N.; Breitbart, H. Role of lipoxygenase in the mechanism of acrosome reaction in mammalian spermatozoa. Biochim. Biophys. Acta (BBA)-Lipids Lipid MeTable 1990, 1043, 12-18. [CrossRef]

88. Walters, J.L.; De Iuliis, G.N.; Dun, M.D.; Aitken, R.J.; McLaughlin, E.A.; Nixon, B.; Bromfield, E.G. Pharmacological inhibition of arachidonate 15-lipoxygenase (ALOX15) protects human spermatozoa against oxidative stress. Biol. Reprod. 2018, 98, 784-794. [CrossRef] [PubMed]

89. Bromfield, E.G.; Mihalas, B.P.; Dun, M.D.; Aitken, R.J.; McLaughlin, E.A.; Walters, J.L.; Nixon, B. Inhibition of arachidonate 15-lipoxygenase prevents 4-hydroxynonenal-induced protein damage in male germ cells. Biol. Reprod. 2017, 96, 598-609. [CrossRef] [PubMed]

90. Brütsch, S.H.; Wang, C.C.; Li, L.; Stender, H.; Neziroglu, N.; Richter, C.; Kuhn, H.; Borchert, A. Expression of inactive glutathione peroxidase 4 leads to embryonic lethality, and inactivation of the alox15 gene does not rescue such knock-in mice. Antioxid. Redox Signal. 2015, 22, 281-293. [CrossRef] [PubMed]

91. Gregus, A.M.; Dumlao, D.S.; Wei, S.C.; Norris, P.C.; Catella, L.C.; Meyerstein, F.G.; Buczynski, M.W.; Steinauer, J.J.; Fitzsimmons, B.L.; Yaksh, T.L.; et al. Systematic analysis of rat 12/15-lipoxygenase enzymes reveals critical role for spinal eLOX3 hepoxilin synthase activity in inflammatory hyperalgesia. FASEB J. 2013, 27, 1939-1949. [CrossRef] [PubMed]

92. Sadeghian, H.; Jabbari, A. 15-Lipoxygenase inhibitors: A patent review. Expert Opin. Ther. Pat. 2016, 26, 65-88. [CrossRef] [PubMed]

93. Sendobry, S.M.; Cornicelli, J.A.; Welch, K.; Bocan, T.; Tait, B.; Trivedi, B.K.; Colbry, N.; Dyer, R.D.; Feinmark, S.J.; Daugherty, A. Attenuation of diet-induced atherosclerosis in rabbits with a highly selective 15-lipoxygenase inhibitor lacking significant antioxidant properties. Bri. J. Pharmacol. 1997, 120, 1199-1206. [CrossRef] [PubMed]

94. Sordillo, L.M.; Weaver, J.A.; Cao, Y.Z.; Corl, C.; Sylte, M.J.; Mullarky, I.K. Enhanced 15-HPETE production during oxidant stress induces apoptosis of endothelial cells. Prostaglandins Other Lipid Med. 2005, 76, $19-34$. [CrossRef] [PubMed] 
95. Bocan, T.M.; Rosebury, W.S.; Mueller, S.B.; Kuchera, S.; Welch, K.; Daugherty, A.; Cornicelli, J.A. A specific 15-lipoxygenase inhibitor limits the progression and monocyte-macrophage enrichment of hypercholesterolemia-induced atherosclerosis in the rabbit. Atherosclerosis 1998, 136, 203-216. [CrossRef]

96. Tobaben, S.; Grohm, J.; Seiler, A.; Conrad, M.; Plesnila, N.; Culmsee, C. Bid-mediated mitochondrial damage is a key mechanism in glutamate-induced oxidative stress and AIF-dependent cell death in immortalized HT-22 hippocampal neurons. Cell Death Differ. 2011, 18, 282-292. [CrossRef] [PubMed]

97. Zhou, L.; Qian, J.; Liu, J.; Zhao, R.; Li, B.; Wang, R. Identification of the sites of 4-hydroxy-2-nonenal and neprilysin adduction using a linear trap quadrapole Velos Pro-Orbitrap Elite mass spectrometer. Eur. J. Mass Spectrom. 2016, 22, 133-139. [CrossRef] [PubMed]

98. Tsirulnikov, K.; Abuladze, N.; Bragin, A.; Faull, K.; Cascio, D.; Damoiseaux, R.; Schibler, M.J.; Pushkin, A. Inhibition of aminoacylase 3 protects rat brain cortex neuronal cells from the toxicity of 4-hydroxy-2-nonenal mercapturate and 4-hydroxy-2-nonenal. Toxicol. Appl. Pharmacol. 2012, 263, 303-314. [CrossRef] [PubMed]

99. Siegel, S.J.; Bieschke, J.; Powers, E.T.; Kelly, J.W. The oxidative stress metabolite 4-hydroxynonenal promotes Alzheimer protofibril formation. Biochemistry 2007, 46, 1503-1510. [CrossRef] [PubMed]

100. Chu, J.; Li, J.G.; Giannopoulos, P.F.; Blass, B.E.; Childers, W.; Abou-Gharbia, M.; Pratico, D. Pharmacologic blockade of 12/15-lipoxygenase ameliorates memory deficits, A $\beta$ and tau neuropathology in the triple-transgenic mice. Mol. Psychiatry 2015, 20, 1329. [CrossRef] [PubMed]

101. Di Meco, A.; Li, J.G.; Blass, B.E.; Abou-Gharbia, M.; Lauretti, E.; Praticò, D. 12/15-Lipoxygenase inhibition reverses cognitive impairment, brain amyloidosis, and tau pathology by stimulating autophagy in aged triple transgenic mice. Biol. Psychiatry. 2017, 81, 92-100. [CrossRef] [PubMed]

102. Okhovati, M.; Zare, M.; Zare, F.; Bazrafshan, M.S.; Bazrafshan, A. Trends in Global Assisted Reproductive Technologies Research: A Scientometrics study. Electr. Phys. 2015, 7, 1597-1601. [CrossRef] [PubMed]

103. Dyer, S.; Chambers, G.M.; de Mouzon, J.; Nygren, K.G.; Zegers-Hochschild, F.; Mansour, R.; Ishihara, O.; Banker, M.; Adamson, G.D. International Committee for Monitoring Assisted Reproductive Technologies world report: Assisted reproductive technology 2008, 2009 and 2010. Hum. Reprod. 2016, 31, 1588-1609. [CrossRef] [PubMed]

104. Mansour, R.; Ishihara, O.; Adamson, G.D.; Dyer, S.; de Mouzon, J.; Nygren, K.G.; Sullivan, E.; Zegers-Hochschild, F. International Committee for Monitoring Assisted Reproductive Technologies world report: Assisted reproductive technology 2006. Hum. Reprod. 2014, 29, 1536-1551. [CrossRef] [PubMed]

105. Rex, A.; Aagaard, J.; Fedder, J. DNA fragmentation in spermatozoa: A historical review. Andrology 2017, 5, 622-630. [CrossRef] [PubMed]

106. Gao, J.; He, X.; Cai, Y.; Wang, L.; Fan, X. Association between assisted reproductive technology and the risk of autism spectrum disorders in the offspring: A meta-analysis. Sci. Rep. 2017, 7, 46207.

107. Hart, R.; Norman, R.J. The longer-term health outcomes for children born as a result of IVF treatment. Part II-Mental health and development outcomes. Hum. Reprod. Update 2013, 19, 244-250. [CrossRef] [PubMed]

108. Aitken, R.J.; De Iuliis, G.N.; Finnie, J.M.; Hedges, A.; McLachlan, R.I. Analysis of the relationships between oxidative stress, DNA damage and sperm vitality in a patient population: Development of diagnostic criteria. Hum. Reprod. 2010, 25, 2415-2426. [CrossRef] [PubMed]

109. Ahmadi, S.; Bashiri, R.; Ghadiri-Anari, A.; Nadjarzadeh, A. Antioxidant supplements and semen parameters: An evidence based review. Int. J. Reprod. Biomed. 2016, 14, 729-736. [CrossRef]

110. Ross, C.; Morriss, A.; Khairy, M.; Khalaf, Y.; Braude, P.; Coomarasamy, A.; El-Toukhy, T. A systematic review of the effect of oral antioxidants on male infertility. Reprod. Biomed. Online 2010, 20, 711-723. [CrossRef] [PubMed]

111. Majzoub, A.; Agarwal, A. Systematic review of antioxidant types and doses in male infertility: Benefits on semen parameters, advanced sperm function, assisted reproduction and live-birth rate. Arab J. Urol. 2018, 16, 113-124. [CrossRef] [PubMed]

112. Comhaire, F.H.; Garem, Y.E.; Mahmoud, A.H.; Eertmans, F.; Schoonjans, F.R. Combined conventional/antioxidant "Astaxanthin" treatment for male infertility: A double blind, randomized trial. Asian J. Androl. 2005, 7, 257-262. [CrossRef] [PubMed]

113. Cavallini, G.; Ferraretti, A.P.; Gianaroli, L.; Biagiotti, G.; Vitali, G. Cinnoxicam and L-carnitine/acetyl-L-carnitine treatment for idiopathic and varicocele-associated oligoasthenospermia. J. Androl. 2004, 25, 761-770. [CrossRef] [PubMed] 
114. Tremellen, K.; Miari, G.; Froiland, D.; Thompson, J. A randomised control trial examining the effect of an antioxidant (Menevit) on pregnancy outcome during IVF-ICSI treatment. Aust. N. Z. J. Obstet. Gynaecol. 2007, 47, 216-221. [CrossRef] [PubMed]

115. Suleiman, S.A.; Ali, M.E.; Zaki, Z.M.; El-Malik, E.M.; Nasr, M.A. Lipid peroxidation and human sperm motility: Protective role of vitamin E. J. Androl. 1996, 17, 530-537. [PubMed]

116. Omu, A.E.; Dashti, H.; Al-Othman, S. Treatment of asthenozoospermia with zinc sulphate: Andrological, immunological and obstetric outcome. Eur. J. Obstet. Gynecol. Reprod. Biol. 1998, 79, 179-184. [CrossRef]

117. Lenzi, A.; Culasso, F.; Gandini, L.; Lombardo, F.; Dondero, F. Andrology: Placebo-controlled, double-blind, cross-over trial of glutathione therapy in male infertility. Hum. Reprod. 1993, 8, 1657-1662. [CrossRef] [PubMed]

118. Gupta, N.P.; Kumar, R. Lycopene therapy in idiopathic male infertility-a preliminary report. Int. Urol. Nephrol. 2002, 34, 369-372. [CrossRef] [PubMed]

119. Safarinejad, M.R.; Safarinejad, S. Efficacy of selenium and/or N-acetyl-cysteine for improving semen parameters in infertile men: A double-blind, placebo controlled, randomized study. J. Urology 2009, 181, 741-751. [CrossRef] [PubMed]

120. Scott, R.; MacPherson, A.; Yates, R.W.; Hussain, B.; Dixon, J. The effect of oral selenium supplementation on human sperm motility. Br. J. Urol. 1998, 82, 76-80. [CrossRef] [PubMed]

121. Hadwan, M.H.; Almashhedy, L.A.; Alsalman, A.R.S. Oral zinc supplementation restore high molecular weight seminal zinc binding protein to normal value in Iraqi infertile men. BMC Urol. 2012, 12, 32. [CrossRef] [PubMed]

122. Hadwan, M.H.; Almashhedy, L.A.; Alsalman, A.R.S. Study of the effects of oral zinc supplementation on peroxynitrite levels, arginase activity and NO synthase activity in seminal plasma of Iraqi asthenospermic patients. Reprod. Biol. Endocrinol. 2014, 12, 1. [CrossRef] [PubMed]

123. Balercia, G.; Buldreghini, E.; Vignini, A.; Tiano, L.; Paggi, F.; Amoroso, S.; Ricciardo-Lamonica, G.; Boscaro, M.; Lenzi, A.; Littarru, G. Coenzyme Q10 treatment in infertile men with idiopathic asthenozoospermia: A placebo-controlled, double-blind randomized trial. Fertil. Steril. 2009, 91, 1785-1792. [CrossRef] [PubMed]

124. Nadjarzadeh, A.; Shidfar, F.; Amirjannati, N.; Vafa, M.R.; Motevalian, S.A.; Gohari, M.R.; Nazeri Kakhki, S.A.; Akhondi, M.M.; Sadeghi, M.R. Effect of Coenzyme Q10 supplementation on antioxidant enzymes activity and oxidative stress of seminal plasma: A double-blind randomised clinical trial. Andrologia 2014, 46, 177-183. [CrossRef] [PubMed]

125. Ebisch, I.M.; Pierik, F.H.; De Jong, F.H.; Thomas, C.M.; Steegers-Theunissen, R.P. Does folic acid and zinc sulphate intervention affect endocrine parameters and sperm characteristics in men? Int. J. Androl. 2006, 29, 339-345. [CrossRef] [PubMed]

126. Wong, W.Y.; Merkus, H.M.; Thomas, C.M.; Menkveld, R.; Zielhuis, G.A.; Steegers-Theunissen, R.P. Effects of folic acid and zinc sulfate on male factor subfertility: A double-blind, randomized, placebo-controlled trial. Fertil. Steril. 2002, 77, 491-498. [CrossRef]

127. Lenzi, A.; Sgro, P.; Salacone, P.; Paoli, D.; Gilio, B.; Lombardo, F.; Santulli, M.; Agarwal, A.; Gandini, L. A placebo-controlled double-blind randomized trial of the use of combined l-carnitine and l-acetyl-carnitine treatment in men with asthenozoospermia. Fertil. Steril. 2004, 81, 1578-1584. [CrossRef] [PubMed]

128. Balercia, G.; Regoli, F.; Armeni, T.; Koverech, A.; Mantero, F.; Boscaro, M. Placebo-controlled double-blind randomized trial on the use of L-carnitine, L-acetylcarnitine, or combined L-carnitine and L-acetylcarnitine in men with idiopathic asthenozoospermia. Fertil. Steril. 2005, 84, 662-671. [CrossRef] [PubMed]

129. Nadjarzadeh, A.; Sadeghi, M.R.; Amirjannati, N.; Vafa, M.R.; Motevalian, S.A.; Gohari, M.R.; Akhondi, M.A.; Yavari, P.; Shidfar, F. Coenzyme Q10 improves seminal oxidative defense but does not affect on semen parameters in idiopathic oligoasthenoteratozoospermia: A randomized double-blind, placebo controlled trial. J. Endocrinol. Investig. 2011, 34, e224-e228.

130. Raigani, M.; Yaghmaei, B.; Amirjannti, N.; Lakpour, N.; Akhondi, M.M.; Zeraati, H.; Hajihosseinal, M.; Sadeghi, M.R. The micronutrient supplements, zinc sulphate and folic acid, did not ameliorate sperm functional parameters in oligoasthenoteratozoospermic men. Andrologia 2014, 46, 956-962. [CrossRef] [PubMed]

131. Sigman, M.; Glass, S.; Campagnone, J.; Pryor, J.L. Carnitine for the treatment of idiopathic asthenospermia: A randomized, double-blind, placebo-controlled trial. Fertil. Steril. 2006, 85, 1409-1414. [CrossRef] [PubMed] 
132. Adewoyin, M.; Ibrahim, M.; Roszaman, R.; Isa, M.; Alewi, N.; Rafa, A.; Anuar, M. Male infertility: The effect of natural antioxidants and phytocompounds on seminal oxidative stress. Diseases 2017, 5, 9. [CrossRef] [PubMed]

133. Mihalas, B.P.; Iuliis, G.N.; Redgrove, K.A.; McLaughlin, E.A.; Nixon, B. The lipid peroxidation product 4-hydroxynonenal contributes to oxidative stress-mediated deterioration of the ageing oocyte. Sci. Rep. 2017, 7, 6247. [CrossRef] [PubMed]

134. Lord, T.; Martin, J.H.; Aitken, R.J. Accumulation of electrophilic aldehydes during postovulatory aging of mouse oocytes causes reduced fertility, oxidative stress, and apoptosis. Biol. Reprod. 2015, 92, 1-13. [CrossRef] [PubMed]

135. Walshe, J. Penicillamine neurotoxicity: An hypothesis. ISRN neurology 2011, 2011, 464572. [CrossRef] [PubMed]

136. Gharagozloo, P.; Gutiérrez-Adán, A.; Champroux, A.; Noblanc, A.; Kocer, A.; Calle, A.; Pérez-Cerezales, S.; Pericuesta, E.; Polhemus, A.; Moazamian, A.; et al. A novel antioxidant formulation designed to treat male infertility associated with oxidative stress: Promising preclinical evidence from animal models. Hum. Reprod. 2016, 31, 252-262. [CrossRef] [PubMed]

137. Elharram, A.; Czegledy, N.M.; Golod, M.; Milne, G.L.; Pollock, E.; Bennett, B.M.; Shchepinov, M.S. Deuterium-reinforced polyunsaturated fatty acids improve cognition in a mouse model of sporadic Alzheimer's disease. FEBS J. 2017, 284, 4083-4095. [CrossRef] [PubMed]

138. Berbée, J.F.; Mol, I.M.; Milne, G.L.; Pollock, E.; Hoeke, G.; Lütjohann, D.; Monaco, C.; Rensen, P.C.; van der Ploeg, L.H.; Shchepinov, M.S. Deuterium-reinforced polyunsaturated fatty acids protect against atherosclerosis by lowering lipid peroxidation and hypercholesterolemia. Atherosclerosis 2017, 264, 100-107. [CrossRef] [PubMed]

139. Cotticelli, M.G.; Crabbe, A.M.; Wilson, R.B.; Shchepinov, M.S. Insights into the role of oxidative stress in the pathology of Friedreich ataxia using peroxidation resistant polyunsaturated fatty acids. Redox Biol. 2013, 1, 398-404. [CrossRef] [PubMed]

140. Hill, S.; Lamberson, C.R.; Xu, L.; To, R.; Tsui, H.S.; Shmanai, V.V.; Bekish, A.V.; Awad, A.M.; Marbois, B.N.; Cantor, C.R.; et al. Small amounts of isotope-reinforced polyunsaturated fatty acids suppress lipid autoxidation. Free Radic. Biol. Med. 2012, 53, 893-906. [CrossRef] [PubMed]

141. Galatioto, G.P.; Gravina, G.L.; Angelozzi, G.; Sacchetti, A.; Innominato, P.F.; Pace, G.; Ranieri, G.; Vicentini, C. May antioxidant therapy improve sperm parameters of men with persistent oligospermia after retrograde embolization for varicocele? World J. Urol. 2008, 26, 97-102. [CrossRef] [PubMed]

142. Ciftci, H.; Verit, A.; Savas, M.; Yeni, E.; Erel, O. Effects of N-acetylcysteine on semen parameters and oxidative/antioxidant status. Urology 2009, 74, 73-76. [CrossRef] [PubMed]

143. Safarinejad, M.R.; Safarinejad, S.; Shafiei, N.; Safarinejad, S. Effects of the reduced form of coenzyme Q10 (ubiquinol) on semen parameters in men with idiopathic infertility: A double-blind, placebo controlled, randomized study. J. Urol. 2012, 188, 526-531. [CrossRef] [PubMed]

144. Greco, E.; Iacobelli, M.; Rienzi, L.; Ubaldi, F.; Ferrero, S.; Tesarik, J. Reduction of the incidence of sperm DNA fragmentation by oral antioxidant treatment. J. Androl. 2005, 26, 349-353. [CrossRef] [PubMed]

145. Rolf, C.; Cooper, T.G.; Yeung, C.H.; Nieschlag, E. Antioxidant treatment of patients with asthenozoospermia or moderate oligoasthenozoospermia with high-dose vitamin C and vitamin E: A randomized, placebo-controlled, double-blind study. Hum. Reprod. 1999, 14, 1028-1033. [CrossRef] [PubMed]

146. Greco, E.; Romano, S.; Iacobelli, M.; Ferrero, S.; Baroni, E.; Minasi, M.G.; Ubaldi, F.; Rienzi, L.; Tesarik, J. ICSI in cases of sperm DNA damage: Beneficial effect of oral antioxidant treatment. Hum. Reprod. 2005, 20, 2590-2594. [CrossRef] [PubMed]

147. Moslemi, M.K.; Tavanbakhsh, S. Selenium-vitamin E supplementation in infertile men: Effects on semen parameters and pregnancy rate. Int. J. Gen. Med. 2011, 4, 99-104. [CrossRef] [PubMed]

148. Keskes-Ammar, L.; Feki-Chakroun, N.; Rebai, T.; Sahnoun, Z.; Ghozzi, H.; Hammami, S.; Zghal, K.; Fki, H.; Damak, J.; Bahloul, A. Sperm oxidative stress and the effect of an oral vitamin E and selenium supplement on semen quality in infertile men. Arch. Androl. 2003, 49, 83-94. [CrossRef] [PubMed]

(C) 2018 by the authors. Licensee MDPI, Basel, Switzerland. This article is an open access article distributed under the terms and conditions of the Creative Commons Attribution (CC BY) license (http://creativecommons.org/licenses/by/4.0/). 